\title{
口腔外科患者におけるメチシリン耐性黄色ブドウ球菌の検出状況
}

一特に口唇・口蓋裂児について——

\author{
根岸明秀・吉増秀實・坂本紀代美・塩入重 彰 \\ 天笠光雄・榎本昭二*
}

\section{Methicillin-resistant Staphylococcus aureus carriers in infants with cleft lip and palate}

\author{
Akihide Negishi $\cdot$ Hidemi Yoshimasu $\cdot$ Kiyomi SaKamoto \\ Shigeaki ShiolRI $\cdot$ Teruo Amagasa $\cdot$ Shoji Enomoto*
}

\begin{abstract}
Outbreaks of methicillin-resistant Staphylococcus aureus (MRSA) show signs of resolving owing to strict infection control at hospitals recently. Nevertheless, some MRSA carriers and infected patients are detected. There are several reports about infants with MRSA infection at neonatal intensive care units, but very few about infants who are MRSA carriers.

We have examined the MRSA carrier status of all patients before admission since September 1991. There were 5 infants who were MRSA carriers among 55 patients with cleft lip or palate, or both, who were examined before primary surgery. All cases involved complete cleft lip and palate. Hotz type palatal plates were inserted in 4 patients, and 4 patients had previously visited or been admitted to other hospitals, but we could not determine the route of infection. After application of povidone iodine to the oro-nasal cavity and to the palatal plates, we did not detect MRSA in any patient. Although MRSA had disappeared from the oro-nasal area, it was redetected in some cases.

We conclude that:

1 ) Before admission, some infants are MRSA carriers.

2 ) Examinations for MRSA are necessary to protect infants against nosocomial infections.

3 ) Povidone iodine is effective for MRSA carriers.

4) A Hotz type palatal plate is useful for the povidone iodine treatment of patients with cleft lip and palate.

5 ) To control hospital-acquired infections, MRSA carriers should be managed in a single room, even if MRSA is not detected.
\end{abstract}

Key words: methicillin-resistant Staphylococcus aureus (メチシリン耐性黄色ブドウ球菌), cleft lip and palate (口唇・口蓋裂), hospital infection control (院内感染対策)

東京医科歯科大学歯学部口腔外科学第 1 講座

(主任 : 天笠光雄教授)

*東京医科歯科大学歯学部口腔外科学第 2 講座 (主任 : 榎本昭二教授)

1 st Department of Oral and Maxillofacial Surgery, Faculty of Dentistry, Tokyo Medical and
Dental University (Chief: Prof. Teruo Amagasa)

* 2 nd Department of Oral and Maxillofacial Surgery, Faculty of Dentistry, Tokyo Medical and Dental University (Chief: Prof. Shoji Enomoto) 受付日: 平成 9 年 9 月 19 日 
緒

言

メチシリン耐性黄色ブドウ球菌（以下 MRSA）は 院内感染の原因菌として臨床上問題となってから 10 年 以上経過している ${ }^{1)}$. 最近では, 院内感染対策が徹底 され，また，抗生物質の適正使用がなされるようにな り, MRSA の感染例は減少傾向にあるが, MRSA 保 菌者や感染患者のコントロールには少なからず問題が ある ${ }^{2}$.

黄色ブドウ球菌は, 口腔外科領域の手術部位である 口腔・鼻腔粘膜の常在菌であり, 歯科口腔外科受診患 者の中に, 不顕性の MRSA 保菌者がおり問題となっ ている ${ }^{3)}$. また, MRSA が口腔外科手術後の創感染の 起炎菌となり，その後慢性骨髄炎へ移行し，対処に苦 慮したとの報告もある ${ }^{4}$ ．

口唇・口蓋裂児は, 口腔と鼻腔が連続する形態を有 し，また入院・手術を受ける機会が多いことから， MRSA 等の細菌感染を生じる可能性が高いと思われ る.しかしながら，これまで本疾患の MRSA の保菌 あるいは感染状況に関する報告は見られない。

当院では, 院内感染対策として, 1991年 9 月より入 院予定患者全例に対し, 咽頭および鼻腔粘液を検体と し, 細菌培養検査を行っている ${ }^{5,6)}$.

本論文では, 当院における MRSA 検出の背景とし て, 口腔外科入院予定患者の MRSA 検出状況を調査 するとともに, 特に一次手術前の口唇・口蓋裂児にお ける検出例について検討を加え, 報告する.

\section{対象および方法}

\section{1. 対 象}

1991年 9 月から1994年 5 月までに当院にて入院前検 查を施行した 1,781 例について MRSA 検出状況を調 查した。 また,このうち同時期に当科にて一次手術を 行った口唇・口蓋裂児55例については詳細に検討した.

表 1 MRSA 判定法

\begin{tabular}{|c|c|c|c|c|c|}
\hline & $\begin{array}{l}\text { グラム } \\
\text { 染 色 }\end{array}$ & $\begin{array}{l}\text { マンニット } \\
\text { 分 解 能 }\end{array}$ & $\begin{array}{l}\text { 的 } \\
\text { 産 }\end{array}$ & $\begin{array}{l}\text { Pグラーゼ } \\
\text { 生 能 }\end{array}$ & $\begin{array}{l}\text { オキサシリン } \\
\text { 感 受 性 }\end{array}$ \\
\hline $\begin{array}{l}\text { S. aureus } \\
\text { (MRSA) }\end{array}$ & $\begin{array}{l}\text { 陽性 } \\
\text { 球菌 }\end{array}$ & + & & + & $(4 \mu \mathrm{g} / \mathrm{ml}<)$ \\
\hline $\begin{array}{r}\text { S. aureus } \\
\text { (MSSA) }\end{array}$ & $\begin{array}{l}\text { 陽性 } \\
\text { 球菌 }\end{array}$ & + & & + & $\left(2 \mu \mathrm{g}^{+} / \mathrm{ml}>\right)$ \\
\hline S. intermedis & $\begin{array}{l}\text { 陽性 } \\
\text { 球菌 }\end{array}$ & - & & + & $+/-$ \\
\hline S. saprophyticus & $\begin{array}{l}\text { 陽性 } \\
\text { 球菌 }\end{array}$ & $+1-$ & & - & $+1-$ \\
\hline S. epidermidis & $\begin{array}{l}\text { 陽性 } \\
\text { 球菌 }\end{array}$ & - & & - & $+/-$ \\
\hline
\end{tabular}

55 例の検查時年齢は 3 か月から 4 歳 6 か月であり, 裂 型は片側唇 (顎) 裂10例, 両側唇 (顎) 裂 4 例, 片側唇 顎口蓋裂19例, 両側唇顎口蓋裂11例，口蓋裂11例であっ た。

\section{2 . 検体採取法}

滅菌綿棒により鼻前庭および咽頭粘膜を擦過して得 た粘液を検体とした ${ }^{5}$ ).

\section{3 . 検出法}

検体はブドウ球菌選択培地であるマンニット食塩培 地にて $37^{\circ} \mathrm{C}, 1 \sim 2$ 日間分離培養を行った. 培地上に 発育したブドウ球菌のコロニーを釣菌し, BrainHeart-Infusion ブイヨンにて $37^{\circ} \mathrm{C}, 2 \sim 24$ 時間培養を 行い, 増殖させた. 発育したコロニー菌群に対し,グ ラム染色による形態学的検査, マンニット分解能の有 無, コアグラーゼ産生の有無, オキサシリン感受性を 検索した. 判定は, グラム陽性球菌で, マンニット分 解能拉よびコアグラーゼ産生能を有する菌群を黄 色ブドウ球菌とし, その中で, オキサシリン濃度が $4 \mu \mathrm{g} / \mathrm{ml}$ 以上で発育可能であった菌群を MRSA と した5, 7９）(表 1 ).

\section{結果}

\section{1. 入院前検査における MRSA 検出状況}

1991年 9 月から1994年 5 月までの当院全体の入院前 検查施行患者 1,781 例中, MRSA が検出された症例は 33例 $(1.9 \%)$ であった. 疾患別では口唇・口蓋裂219 例中 12 例 $(5.5 \%)$, このうち一次手術症例 71 例中 8 例 $(11.3 \%)$, 二次手術症例148 例中 4 例 $(2.7 \%)$, 悪性腫 瘍 486 例中 11 例 $(2.3 \%)$, 震胞性疾患 148 例中 3 例 $(2.0$ $\%)$, 顎変形症 240 症例中 2 例 $(0.8 \%)$, その他668 例 中 5 例 $(0.7 \%)$ であった (表 2 ).

検出症例中, 当科の症例は, 口唇 - 口蓋裂一次手術 症例 5 例, 悪性腫瘍 6 例, 囊胞性疾患 2 例, その他 3 例 であり, 口唇・口蓋裂二次手術症例および顎変形症で

表 2 当院入院前検査における MRSA 検出状況 疾患別分布 (1991年 9 月～1994年 5 月）

\begin{tabular}{|c|c|c|c|c|}
\hline 疾 患 名 & 例数 & $\begin{array}{l}M R \\
\text { 当科 }\end{array}$ & $\begin{array}{l}\text { SA 陽性数 } \\
\text { 第 } 2 \text { 口腔外科 }\end{array}$ & 計 (\%) \\
\hline 口唇·口蓋裂 & 219 & 5 & 7 & $12(5.5)$ \\
\hline — 一次手術症例 & 71 & 5 & 3 & $8(11.3)$ \\
\hline L 二次手術症例 & 148 & 0 & 4 & $4(2.7)\rfloor$ \\
\hline 悪性腫瘍 & 486 & 6 & 5 & $11(2.3)$ \\
\hline 囊胞性疾患 & 148 & 2 & 1 & $3(2.0)$ \\
\hline 顎変形症 & 240 & 0 & 2 & $2(0.8)$ \\
\hline その他 & 688 & 3 & 2 & $5(0.7)$ \\
\hline 計 & 1781 & 16 & 17 & $33(1.9)$ \\
\hline
\end{tabular}


は認められなかった（表 2 ).

年齢別検出状況では，0歳から80歳以上まで広く分 布しているが, 10歳未満および60歳台に多く検出され た（表 3 ).

\section{2 . 当科の口唇・口蓋裂一次手術症例における術} 前 MRSA 検出状況

当科において口唇・口蓋裂に対する一次手術が計画 された55例では, 入院前検査にて 5 例に MRSA が検 出された. コアグラーゼ型は全例 II 型であった，検出 された患児の性別は男児 4 例，女児 1 例であった。裂 型は片側唇顎口蓋裂 3 例, 両側唇䫟口蓋裂 2 例の計 5 例で，すべて完全唇顎口蓋裂であり，唇（顎）裂，口蓋 裂単独例では見られなかった（表 4 ）.

3. MRSA 検出症例の経過と処置 (表 5,6 ) 症例 1

患 者：1歳10か月, 男児, 右唇顎口蓋裂.

初 診: 1990年 4 月

既往歴：1989年 3 月】某産院にて出生. 出生時よ り呼吸状態不良のため, 同日某医科大学病院に搬送さ

表 3 当院入院前検査における MRSA 検出状況 年齢別分布（1991年 9 月～1994年 5 月）

\begin{tabular}{c|rcc}
\hline 年齢 & 例数 & MRSA 陽性数 & $\%$ \\
\hline $0 \sim$ & 105 & 9 & 8.6 \\
$10 \sim$ & 192 & 3 & 1.6 \\
$20 \sim$ & 463 & 2 & 0.4 \\
$30 \sim$ & 151 & 1 & 0.7 \\
$40 \sim$ & 195 & 2 & 1.0 \\
$50 \sim$ & 287 & 4 & 1.4 \\
$60 \sim$ & 215 & 8 & 3.7 \\
$70 \sim$ & 121 & 3 & 2.5 \\
$80 \sim$ & 52 & 1 & 1.9 \\
\hline 計 & 1781 & 33 & 1.9 \\
\hline
\end{tabular}

れ新生児集中治療部（NICU）に入院.入院時より肺 炎を認め抗生物質投与. 4 月以動脈管開存症に対し 動脈管結紮術施行. 5 月初旬より一過性心筋症に対し 血管拡張剂を投与された。 7 月喉頭軟化症と診断 され，その後も肺炎等繰り返し，抗生物質の投与を頻 回に受けた。

現病歴：出生時より哺乳障害のため, 胃管にて哺乳. 1990年 2 月同大学病院形成外科受診するも，経口哺乳 不可能なため手術は不可との診断.4月唇顎口蓋 裂の治療を希望し，当科を受診した。

経 過：1990年 4 月— Hotz 型人工口蓋床装着．5 月同大学病院耳鼻科にて高度難聴および両側滲出 性中耳炎を指摘された。1991年 4 月術前評価のため， 本学小児科に入院し, 全身麻酔および手術が可能と診 断された. 5 月—気管支炎のため再び同科に入院し， 抗生物質の投与を受けた. 6 月—当科にて全身麻醉 下に右口唇形成術が施行されたが，この時点では MRSA に関する入院前検查は施行されておらず，保 菌状況は不明であった. 1993年 7 月 2 日入院前検査に て咽頭および鼻腔粘液より MRSA が検出されたため, ポビドンヨード製剂を鼻腔, 口腔および Hotz 型人工 口蓋床に塗布する方法による除菌を開始した， 7 月 口以降 3 回の検査にて MRSA 陰性となったため, 9

表 4 当科の口唇・口蓋裂一次手術例における MRSA 検出状況

(1991年 9 月～1994年 5 月）

\begin{tabular}{|c|c|c|c|}
\hline 裂 型 & 例 数 & MRSA 陽性数 & $\%$ \\
\hline 片側唇（顎）裂 & 10 & 0 & 0 \\
\hline 両側唇 (顎) 裂 & 4 & 0 & 0 \\
\hline 片側唇顎口蓋裂 & 19 & 3 & 15.8 \\
\hline 両側唇顎口蓋裂 & 11 & 2 & 18.2 \\
\hline 口 蓋 裂 & 11 & 0 & 0 \\
\hline 計 & 55 & 5 & 9.1 \\
\hline
\end{tabular}

表 5 MRSA 検出症例

\begin{tabular}{|c|c|c|c|c|c|c|c|c|}
\hline \multirow{2}{*}{ 症例 } & \multirow{2}{*}{ 裂 } & \multirow{2}{*}{ 性 } & \multirow{2}{*}{$\begin{array}{l}\text { 初診時 } \\
\text { 年 齢 }\end{array}$} & \multirow{2}{*}{ 初診年月日 } & & & \multirow{2}{*}{$\begin{array}{l}\text { MRSA 検出 } \\
\text { 年 月 }\end{array}$} & \multirow{2}{*}{$\begin{array}{l}\text { MRSA 陰性化 } \\
\text { 確定年月日* }\end{array}$} \\
\hline & & & & & 口唇形成術 & 口蓋形成術 & & \\
\hline 1 & 片側唇顎口蓋裂 & 男児 & $\begin{array}{c}1 \text { 歳 } \\
10 \text { 月 }\end{array}$ & 1990年 4 月 & 1991年 6 月 & 1993年 9 月 & 1993年 7 月 & 1993年 9 月 \\
\hline 2 & 両側唇顎口蓋裂 & 男児 & 1 か月 & 1991年 2 月| & $\begin{array}{l}\text { 1991年 } 7 \text { 月 } \\
\text { 1991年12月 }\end{array}$ & 1994年 4 月 & 1993年 1 月 & 1994年 3 月 \\
\hline 3 & 片側唇顎口蓋裂 & 女児 & 4 出月 & 1992年 8 月 & 1993年 1 月 & 1994年 5 月 & 1993年11月 & 1994年 5 月 \\
\hline 4 & 両側唇顎口蓋裂 & 男児 & 1 出月 & 1992年11月 & $\begin{array}{l}\text { 1993年 } 4 \text { 月 } \\
\text { 1993年 } 9 \text { 月 }\end{array}$ & 1994年 5 月 & 1993年 2 月 & 1993年12月 \\
\hline 5 & 片側唇顎口蓋裂 & 男児 & 3 週 & 1993年 6 月 & 1994年 5 月 & 1994年12月 & 1993年10月 & 1995年 4 月 \\
\hline
\end{tabular}

* : 3 回の検査で MRSA 陰性と判定された場合を陰性化確定年月日とした. 
表 6 MRSA 検出症例の背景因子・処置および経過

\begin{tabular}{|c|c|c|c|c|c|c|}
\hline 症例 & 合併症など & $\begin{array}{l}\text { 他院入院 } \\
\text { 既 往 }\end{array}$ & $\begin{array}{l}\text { Hotz 型 } \\
\text { 人工口蓋床 }\end{array}$ & $\begin{array}{l}\text { 家族から } \\
\text { MRSA 検出 }\end{array}$ & 置 & 経 \\
\hline 1 & $\begin{array}{l}\text { 動脈管開存症 } \\
\text { 㑨頭軟化症 } \\
\text { 両側滲出性中耳炎 } \\
\text { ほか }\end{array}$ & あり & 装着 & なし & $\begin{array}{l}\text { ポビドンョード製剤を } \\
\text { 鼻・腔内, 人工口蓋 } \\
\text { 床に塗布 }\end{array}$ & 2 か月で陰性化 \\
\hline 2 & $\begin{array}{l}\text { 上気道感染 } \\
\text { 肝機能障害 }\end{array}$ & あり & 装着 & なし & $\begin{array}{l}\text { ポビドンヨード製剤を } \\
\text { 鼻・ロ腔内, 人工口蓋 } \\
\text { 床に塗布 }\end{array}$ & $\begin{array}{l}1 \text { か月で陰性化したが, そ } \\
\text { の後検出され, 最終的に } 1 \\
\text { 年 } 2 \text { 月で陰性化 }\end{array}$ \\
\hline 3 & 上気道感染 & なし & 中止 & $\begin{array}{l}\text { あり } \\
\text { (姉) }\end{array}$ & $\begin{array}{l}\text { ポビドンョード製剂を } \\
\text { 鼻・口腔内に塗布 }\end{array}$ & 6 か月で陰性化 \\
\hline 4 & なし & なし & 装着 & $\begin{array}{c}\text { あり } \\
\text { (母親) }\end{array}$ & $\begin{array}{l}\text { ポビドンョード製剂を } \\
\text { 鼻・腔内, 人工口蓋 } \\
\text { 床に塗布 }\end{array}$ & 10か月で陰性化 \\
\hline 5 & なし & あり & 装着 & なし & $\begin{array}{l}\text { ポビドンョード製剤を } \\
\text { 鼻・口腔内, 人工口蓋 } \\
\text { 床に塗布 }\end{array}$ & $\begin{array}{l}3 \text { か月で陰性化したが, そ } \\
\text { の後陽性・陰性を繰り返し, } \\
\text { 最終的に } 1 \text { 年 } 6 \text { 月月で陰性 } \\
\text { 化 }\end{array}$ \\
\hline
\end{tabular}

当科にて全身麻醉下に口蓋形成術および両側鼓 膜切開術を施行した。入院中および退院後とも MRSA は検出されなかった。

\section{症例 2}

患 者：1 只月, 男児, 両側唇顎口蓋裂.

初 診: 1991年 2 月

既往歴 : 特記事項なし.

現病歴：1991年1月某病院にて出生。1月 某大学病院口腔外科を受診. 1 月 Hotz 型人工口 蓋床装着. 居住地の関係で, 当科を紹介された。

経 過: 1991年 7 月—全身麻酔下に左口唇形成術 施行 (入院前 MRSA 未検查). 12 月 MRSA 陰性 のため入院し，12月—右口唇形成術施行。1992年 6 月，8月，11月と 3 回にわたり MRSA 陰性にて，口蓋 形成術目的に入院したが, 上気道感染による発熱や, それに起因すると考えられる肝機能障害のため手術延 期となった. 1993年 1 月】入院前検查にて MRSA が検出され，入院を延期し，症例 1 と同様，ポビドン ヨード製剤による除菌を行った， 2 月， 3 月の 2 回の 細菌検査ではMRSA は検出されなかったが，4月お よび 9 月に検出されたため,さらに除菌を継続した. 1994 年 1 月—以降は 3 回の検查にて MRSA は検出されな かったため，4月】全身麻酔下に口蓋形成術が施行さ れた. 入院中および退院後は MRSA は陰性であった.

\section{症例 3}

患 者：4 只, 女児, 左唇顎口蓋裂.

初 診 : 1992年 8 月 .
既往歴：特記事項なし.

現病歴：1992年 3 月固産院にて出生. 某大学病 院口腔外科受診し, Hotz 型人工口蓋床を装着. しかし, 口蓋床に適心できなかったため装着を中止した。その 後保健所からの紹介により，8月当科受診.

経 過：1992年 9 月—MRSA 㓌性にて口唇形成 術目的に入院したが, 上気道感染による発熱のため中 止. 1993年 1 月只 (MRSA 陰性)，1月28日全身 麻酔下に左口唇形成術施行. 10月 MRSA 陰性に て, 口蓋形成術目的に入院したが, 発熱のため中止。 11月】入院前検查にて MRSA が検出され, ポビド ンヨード製剤塗布により除菌開始. 1994年 4 月—以 降 3 回にわたり MRSA が検出されなかったため，5 月—全身麻酔下に口蓋形成術施行. 入院中および退 院後 MRSA は検出されなかった。なお，家族におけ るMRSA 保菌状況を検索したところ，両親からは検 出されず, 姉（4歳）の鼻腔から MRSA が検出された。 姉は熱性㾏攣等で医療機関受診の機会が多いとのこと であった. 姉に対しても，ポビドンヨード製剤による 含嗽をすすめ, 陰性化した。

\section{症例 4}

患 者：1 加, 男児, 両側唇顎口蓋裂.

初 診: 1992年11月

既往歴 : 特記事項なし.

現病歴：1992年10月 某産院にて出生. 10月 某市立病院を受診したが, その後当科での治療を希望 $L, 11$ 月当科受診. 
経 過：1992年11月口口 Hotz 型人工口蓋床装着. 1993年 2 月 入入院前検查にて MRSA が検出された ため, ポビドンヨード製剤を Hotz 型人士口蓋床に塗 布することによる除菌を開始した. MRSA 陽性であっ たが, 手術時期として適切な月齢であったため, 個室 管理とし，4月—全身麻酔下に左口唇形成術を施行 した. 退院後もMRSA は検出された.9月全身麻 酔下に右口唇形成術を施行した. その後も除菌を継続 し，11月—以降 3 回にわたり MRSA 陰性であった ため, 除菌処置を中止した。1994年 5 月 入院前検 查にてMRSA は検出されず，5月全身麻酔下に 口蓋形成術を施行した。なお，1993年 4 月四初回 入院時，母親から検体を採取したところ, MRSA が検 出されたため, ポビドンヨード製剤による含嗽にて除 菌処置を施行し，同年11月の時点で陰性化した。

\section{症例 5}

\section{患 者：3 週, 男児, 左唇顎口蓋裂。 \\ 初 診: 1993年 6 月}

既往歴：特記事項なし

現病歴：1993年 6 月 $\square$ 某病院にて出生。哺乳障害 のため, 某都立病院未熟児病棟へ転院. 6 月】退院. 6 月紹介され当科受診.

経 過：1993年 7 月 Hotz 型人工口蓋床装着. 10月】入院前検查にて MRSA が検出されたため, ポビドンヨード製剤を Hotz 型人工口蓋床に塗布する 方法にて除菌を開始した. 12月—以降 3 回にわたり MRSA 陰性であったが, 1994年 1 月 入院前検査に て再度検出されたため, 入院を延期した. MRSA 陽性 であったが，手術時期を考慮して，個室に入院し，5 月ロ全身麻酔下に左口唇形成術を施行した，その後 も MRSA の検出が持続したため, 除菌を継続したが, MRSA は陽性であった。個室管理とし，12月全身 麻酔下に口蓋形成術を施行した。術後および退院後に はMRSA は検出されなかった。なお初回入院時，母 親および姉（9歳）に対し細菌検查を施行したが, MRSA は検出されなかった。

\section{考察}

MRSA 感染は, 長期入院患者や悪性腫瘍など基礎 疾患を有する易感染性患者に発生しやすいと言われて いる。したがって，比較的高齢者における感染が問題 になることが多い.MRSA による肺炎や腸炎, 敗血症, 難治性裖瘡などの感染症が惹起された場合, 多剂耐性 であることから治療が困難になることも少なくな い4,10,11). 一方, MRSA の無症候性保菌者も広く分 布しているといわれ，常在菌である黄色ブドウ球菌が 多剂耐性を獲得しつつある状況と考えられている2）。

当院歯科病棟では, 1984年膿汁から MRSA が初め て検出されているが, 1988年までは少数の感染に止まっ
ていた.しかし，1989年に検出された黄色ブドウ球菌 24例中 MRSA は18例と急増し，院内感染対策を強化 した。その結果1990年には12例中 8 例と減少した。と ころが，MRSA が社会的にも問題となった 1991 年に は，当院においても33例中 29 例と増加した．そのため 院内感染予防対策として, 前記のように1991年 9 月よ り入院予定患者全例に対し鼻腔揖よび咽頭粘液の細菌 培養検査をあらかじめ行うようにしており，1992年は 17例中 12 例, 1993 年は 15 例中 7 例と歯科病棟入院患者 からの MRSAの検出は減少した6).

乳幼児における MRSA 感染あるいは保菌状態は, NICU における発生は報告されているものの，その他 の施設からの報告は少ない12 14). 今回の調査で，当院 では口唇・口蓋裂症例は他の疾患と比べ, MRSAの 検出される率がやや高く，特に乳幼児である一次手術 症例において高い検出率であることが示された。また 疾患として，口唇・口蓋裂のみを有し，合併疾患を持 たない乳幼児においても MRSA 保菌者が存在するこ とが明らかとなった。

口唇・口蓋裂児において MRSA 陽性率が高い理由 として，1）乳幼児期から医療機関を受診する機会が 多い. 合併疾患を有する場合, その機会はより増加す る. 2 ) 黄色ブドウ球菌が常在する口腔と鼻腔は, 裂 により広く交通する単一腔となっており，自浄性が不 良で炎症を起こしやすい. 3 ) Hotz 型人工口蓋床等の 人工物を口腔内に装着することが多い，などが考えら れる.すなわち口唇・口蓋裂児は MRSA に接触する 可能性が高く, 鼻, 口腔に保菌状態となった場合, MRSA が常在化しやすいものと推察された。

今回の調查でMRSA が検出された症例では，合併 疾患のため他の医療機関における入院・手術の既往を もつものは 1 例であった. また, 生後未熟児病棟へ入 院した 1 例, 上気道感染を繰り返し外来あるいはは入 院治療の機会が多かった 2 例を含め, 計 4 例が頻回の 治療を受けていた. 裂型については, MRSA 検出例は すべて完全唇顎口蓋裂例であり，唇（顎）裂，口蓋裂 単独例ではみられなかった。したがって, MRSA に接 触する可能性を有し, MRSA が常在化しやすい条件 を有する症例にMRSA 検出例が見られた。

MRSA の感染経路を特定するためには, DNA フィ ンガープリントが有効とされているが15)，当院では施 設の事情から残念ながら行っていない。当院にて施行 している入院前細菌検査は, 院内感染の予防のために 行っているものであり, 大量の検体を 1 名のスタッフ で検査している。このような事情から詳細な検討は不 可能であった.

当院では, MRSA 検出症例に対しては, ポビドンヨー ド含嗽剂による口腔内洗浄ならびにポビドンヨードゲ ル剂の綿棒による鼻腔内への塗布が行われる ${ }^{5)}$ ，しか し，今回のような乳幼児では含嗽は困難である。した 
がってポビドンヨードゲル剤を鼻腔・口腔内へ綿棒に より塗布し, さらに 4 例では Hotz 型人工口蓋床に塗 布して装着する方法を採用した。これらの方法により 全例において MRSA を消失させることができた。

一方, 症例 2，5のように, 一度 MRSA 保菌状態に なると, 除菌により陰性化したとしても，再度検出さ れることがあった. そのため，院内感染の予防として， MRSA 保菌者に対して徹底した除菌を行うだけでな く，可能であれば個室管理により入院・手術を行う方 がより適切であると考えられた。当院においても， 病棟に個室が増設されたため, 症例 4, 5では, MRSA の除菌を行いつつ, 手術を施行した。

以上より，入院前の乳幼児においても MRSA 保菌 者が存在しており，院内感染予防対策として乳幼児に 対しても鼻腔・口腔の細菌検査を行う必要があり，こ れにより院内感染源を減少させうると考えられた。 MRSA 検出症例に対してはポビドンョード製剂は有 用であり, 特に口唇・口蓋裂児では, Hotz 型人工口蓋 床にポビドンヨードゲル剂を塗布する方法がきわめて 有用であった。しかし，一度 MRSA が検出された症 例では，たとえ MRSA が陰性となっても再度 MRSA が検出される可能性があり，個室管理は院内感染予防 対策の観点からより有効と考えられた。

\section{結語}

1991年 9 月から1994年 5 月までに施行された入院前 検査において，1,781 例中 33 例 $(1.9 \%$ \% にMRSA が 検出された. 疾患別では口唇・蓋裂患者に最も多く, 年齢別では10歳末満が多かった.

MRSA の検出された口唇・ 口蓋裂一次手術症例 5 例は全例完全唇顎口蓋裂であり, Hotz 型人工口蓋床 は 4 例に装着，また 4 例に他院受診あるいは入院既往が あった.しかし，その感染経路を特定するには至らなかっ た.

MRSA 検出例に対してポビドンヨード製剤を応用 し全症例除菌できた。除菌には Hotz 型人工口蓋床に ポビドンヨードゲル剂を塗布する方法がきわめて有用 であった。

一度 MRSA が検出された症例はたとえ MRSA が 陰性となっても個室管理として取り扱った方が院内感 染予防対策上有効であると考えられた。

稿を終えるにあたり,ご協力下さいました, 東京医科歯 科大学歯学部附属病院検査部山田祐一先生に深謝いたしま す.

本論文の一部は, 第18回日本口蓋裂学会総会 (1994年 7 月 1 日, 大阪) において発表した.

\section{引用文 献}

1）横田 健：メチシリン・セフェム耐性黄色ブド ウ球菌（MRSA）. 医学のあゆみ 131: 951-956 1984.

2）稲松孝思: MRSA 保菌者とムピロシン. 感染 症 27: 53-58 1997.

3）根岸明秀, 立花忠夫, 他 : 総合病院歯科におけ るメチシリン耐性黄色ブドウ球菌のスクリーニ ング調査一口腔内の保菌状況についてー。日 外誌 38: 615-620 1992.

4) Harada, K. and Enomoto, S.: Bone-like calcified tissue formation in wounds chronically infected with methicillinresistant Staphylococcus aureus: A case report. Int. J. Oral Maxillofac. Surg. 26 (Suppl. 1 ): 250, 1997.

5) 東京医科歯科大学歯学部附属病院：MRSA 院 内感染予防対策ガイドライン. 1992, 1-13 頁.

6）塩入重彰：歯科病棟における MRSA 院内感染 の現状とその対策. 有病者歯科医療 2: 125-131 1994.

7) Waitz, J.A., Doern, G.V., et al.: Performance standards for antimicrobial disk susceptibility tests. 4 th Ed, NCCLS, Pennsylvania, 1990, p17-18.

8) Waitz, J.A., Doern, G.V., et al.: Methods for dilution antimicrobial susceptibility tests for bacteria that grow aerobically. 2 nd Ed, NCCLS, Pennsylvania, 1990, p1314.

9）菅野治重 : 細菌検査における MRSA の判定基 準. 最新医学 44: 2510-2514 1989.

10）田中恭子, 田中輝和，他：Pseudomonas aeruginosa および多剂耐性 Staphylococcus aureus（MRSA）に対する Imipenem と Amikacin の併用効果. 化学療法の領域 5: 506-512 1989 .

11）渡辺 彰, 大泉耕太郎, 他 : 多剂耐性黄色ブド ウ球菌に関する研究 ( III ). Chemotherapy 35: 699-708 1989 .

12）猪狩 淳: MRSA 院内感染の現況と対策. 順 天堂医学 40: 300-305 1994.

13) Jernigan, J.A., Titus, M.G., et al.: Effectiveness of contact isolation during a hospital outbreak of methicillin-resistant Staphylococcus aureus. Am. J. Epidemiol. 143: 496-504 1996.

14）藤田晃三 : 院内感染の現状一小児科領域を中心 として. 北海道医学雑誌 69: 161-165 1994.

15）岸本裕充, 浦出雅裕, 他 : 口腔外科入院患者に おける MRSA 院内感染対策の検討.日口外誌 42: 677-683 1996 . 